\title{
The Preliminary Study on Klungsu (Tamarind Seed) as An Alternative Material for Dental Calculus Remover
}

\author{
Ratnawati Hendari \\ Sulur Joyo Sukendro \\ Sadimin \\ Department of Dental Health, \\ Health Polytechnic, \\ Semarang. \\ E-mail: ratnaagung@yahoo.com \\ Received January 30, 2010; Accepted September 15, 2010
}

\begin{abstract}
This study was aimed at knowing the availability of Klungsu (Tamarind seed) as remover and cleaner for dental calculus. The study followed Completely Randomized Design with three treatments and tested with $\mathrm{F}$ test and Duncan Multiple Range Test. The availability was studied by soaking the calculus and enamel at two concentrations ( 0 and 25\%) of Klungsu and one group without soaking (dry group). The results showed that soaking in Klungsu solution significantly decreased $(p<0.05)$ the strength of dental calculus, but no significantly differences ( $p>0.05)$ were found for enamel. The conclusion could be drawn from this study was klungsu could be used as an alternative cleaning material for removing dental calculus and safe for dental enamel.
\end{abstract}

Keywords: Klungsu, Tamarind seed, dental calculus, enamel.

\section{Introduction}

Tamarind is abundant plants in Indonesia that widely used for spice in Indonesian dishes. Tamarind is also rich in some worthwhile chemical compounds, such as protein $2.8 \%$, fat $0.6 \%$, carbohydrate $62.5 \%$, calcium $0.074 \%$, phospor $0.113 \%$, ferum $0.006 \%$, vitamins, citric acid, tartaric acid, succinic acid, and sugar. ${ }^{1}$ Several studies showed that Tamarind seed is very promising material for supporting dental health due to the abundant, tasteless and cheap in price ${ }^{2}$, and may decrease calculus. ${ }^{3}$ Tamarind plant is known to have a benefit to keep tooth and mouth healthy, as shown by its potential for curing sprue and cleaning the calculus. ${ }^{4,5}$ The later function is performed by the seed that containing albuminoid which might solve the mineral in calculus due to the similarity in chemical structure between albuminoid and mineral. ${ }^{6}$ However, the detail study on the availability of Tamarind seed for removing dental calculus is very limited. Meanwhile, a question rises whether Tamarind may have a bad effect on dental enamel due to the similar composition between calculus and enamel. Calculus contains a lot of mineral, for example $3,67 \%$ calcium phosphate, $13 \%$ calcium carbonate, ferum, blood cell, ephithelial cell, residual food, and bacterial, ${ }^{7}$ while the enamel is composed of calcium salt that makes tooth hard and strong enough to support the teeth function for mastication. $^{8}$ 
This study was aimed at knowing the availability of Tamarind seed for removing the calculus, and to clarify its effect on dental enamel. This was important to be clarified prior to the application for daily using.

\section{Materials and Methods}

Two experiments were done to study the Tamarind seed (Klungsu in Javanese) as calculus remover. Klungsu powder was prepared by removing seed's skin and the seed's meat were then dried and grinding finely.

\subsection{Experiment 1}

This experiment was done to clarify the effect of Klungsu powder on the calculus. Calculus was collected by manual scalling from Dental Clinic of Public Health Center in Semarang. The availability of Klungsu was studied by soaking the calculus at two concentrations ( 0 and $25 \%$ ) of Klungsu solution and one without soaking (dry), as follow, (1) Dry calculus (no soaking); (2) $0 \%$ Klungsu solution (no Klungsu, distilled water only) and (3) $25 \%$ (w/v) Klungsu solution. Each group consisted of 10 pieces of calculus. All the calculus was soaked for 60 minutes prior to measuring the strength.

\subsection{Experiment 2}

Second experiment was done to clarify the effect of Klungsu powder on the enamel. Enamel was prepared by cutting the incicivus primer mesio-distal to be four pieces. The incicivus teeth were collected by extraction from Dental Clinic of Public Health Center in Semarang. The availability of Klungsu was studied by soaking the enamel at two concentration of Klungsu solution and one without soaking (dry), as follow, (1) Dry enamel (no soaking), (2) 0\% Klungsu solution (no Klungsu, distilled water only), (3) $25 \%$ $(w / v)$ Klungsu solution. Each group consisted of ten pieces of enamel. All the enamel was soaked for 60

This study was funded by the project of Risbinnakes-UP3M, Polytechnic of Health, Semarang.

8 minutes prior to measuring the strength. Klungsu solution was made by mixed Klungsu powder with distilled water.

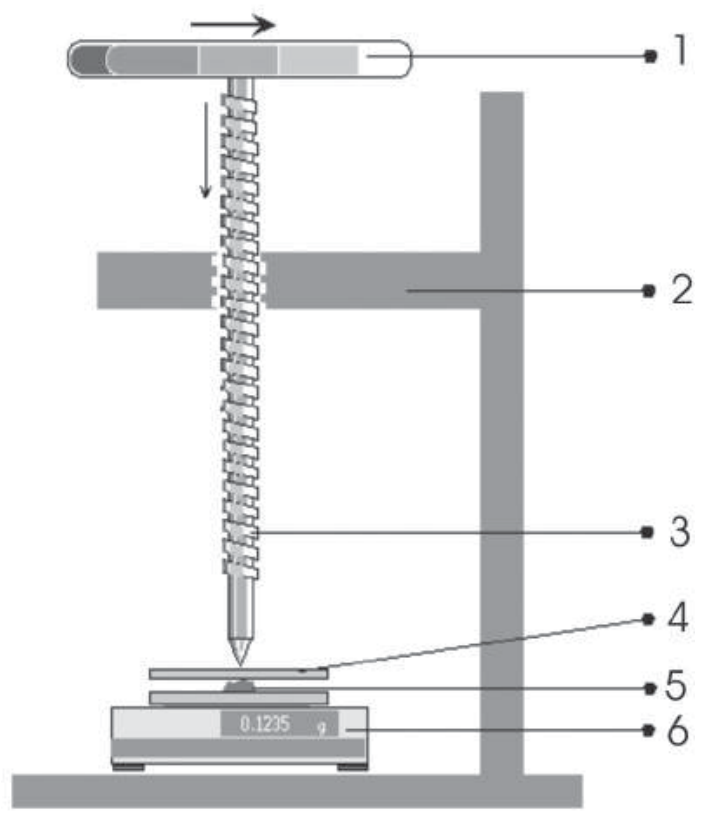

Figure 1. The modified pressing tool used for determining crack point in this study. The parts of this equipment were (1) press driver, (2) standard, (3) pressure bar, (4) iron plate, (5) material measured and (6) electronic balance.

\subsection{Strength measurement}

All the specimens were measured for the weight and the thickness. The weight was measured by electronic scale (Ohauss, Germany) with 200 mg capacity and $1 \mathrm{mg}$ accuracy, while the thickness was measured by sliding calipers. Strength measurement of calculus and enamel was determined by pressing the specimen until it reached crack point. The measurement was done by modified a pressing tool as shown in Figure 1.

The procedure to measure the crack point is as follow: (1) The sample was placed at iron plate, 2) The press driver was turned down to press the specimens, (4) When the specimen started to crack, press was stopped, and the scale was read and 
recorded at the balance. The big scale means the big strength. The strength was then measured by dividing the pressure weight (g) with the sample weight (g) per $\mathrm{cm}$ specimen thickness.

\subsection{Statistical Analysis}

Data were analyzed by F-test and continued by Duncan Multiple Range test ${ }^{9}$ if significant differences were found.

\section{Results and Discussion}

The average of thickness $(\mathrm{mm})$, crack point weight $(\mathrm{kg})$ and strength $(\mathrm{kg} / \mathrm{mm})$ of calculus and enamel are presented in Table 1. The thickness of calculus was varied at range of $1.21-1.70 \mathrm{~mm}$. This variation of thickness was caused by the absence on physical treatment for homogenizing the samples size in avoiding weakened samples prior to measurement. However, in enamel samples the variation in the thickness was pointed to the manual cutting during preparation.

Table 1. The average of thickness, crack point weight and strength of calculus and enamel in this experiment.

\begin{tabular}{|c|c|c|c|}
\hline & Dry & $\begin{array}{c}0 \% \\
\text { Klungsu }\end{array}$ & $\begin{array}{c}25 \% \\
\text { Klungsu }\end{array}$ \\
\hline \multicolumn{4}{|l|}{ Calculus } \\
\hline Thickness (mm) & 1.21 & 1.45 & 1.70 \\
\hline $\begin{array}{l}\text { Crack point } \\
\text { weight }(\mathrm{kg})\end{array}$ & 5.70 & 4.16 & 2.73 \\
\hline $\begin{array}{l}\text { Strength } \\
(\mathrm{kg} / \mathrm{mm})\end{array}$ & $0.41^{a}$ & $0.25^{\mathrm{a}}$ & $0.16^{b}$ \\
\hline \multicolumn{4}{|l|}{ Enamel } \\
\hline Thickness (mm) & 1.50 & 1.60 & 1.77 \\
\hline $\begin{array}{l}\text { Crack point } \\
\text { weight }(\mathrm{kg})\end{array}$ & 88.90 & 85.60 & 79.30 \\
\hline $\begin{array}{l}\text { Strength } \\
(\mathrm{kg} / \mathrm{mm})\end{array}$ & $62.14^{\mathrm{a}}$ & $53.76^{a}$ & $45.20^{\mathrm{a}}$ \\
\hline
\end{tabular}

a, b) different superscript in same line indicated significant difference $(P<0.05)$; $0 \%$ Klungsu was soaked in distilled water
In general, the strength of enamel was around 150 times of calculus, but this value was much higher after being soaked in 0\% (aquadest) and 25\% Klungsu solution, to become 210 and 280 times, respectively. Based on the strength in dry condition, soaking in Klungsu solution showed reduction of the strength of calculus by $40 \%$ in distilled water and by $60 \%$ in $25 \%$ Klungsu solution, but it was found only around 13 and $27 \%$ for enamel strength, respectively. This phenomenon was in line with the statement of Itjiningsih (1991) that enamel is hardest and strongest part of tooth that is able to support the function for mastication.

The crack point weight in calculus and enamel was decreased by soaking in Klungsu solution. As a rule, the crack point weight positively linearly correlated with the thickness. However, the data showed that there was no positive correlation between the thickness and the crack point. These facts indicated that the soaking in Klungsu solution may reduce the strength of the calculus and enamel.

The strength of calculus were significantly $(p<0.05)$ reduced by soaking in $25 \%$ Klungsu solution, but no differences ( $p>0.05$ ) were found between dry and distilled water soaking. The tendency of soaking in Klungsu solution on enamel strength was observed $(p=0.077)$. These phenomena showed that Klungsu has an effect on reducing the strength of the enamel as well as that of calculus.

Based on the data in this study, it is concluded that $25 \%$ Klungsu solution could remove the calculus, but no effect on enamel strength. Therefore, the potential of Tamarind seed as an alternative material for calculus remover was strongly shown. However, this study should be continued to find the best concentration of Klungsu for application, and to find out the active compounds for calculus remover.

\section{Acknowledgment}

The authors thank to drg. Henry Setiawan, MS of Public Health Faculty, Diponegoro University for reviewing the proposal and proof reading this manuscript. This study was funded by the project of Risbinnakes-UP3M, Polytechnic of Health, Semarang. 
Hendari et al.

\section{References}

1. IPTEKnet. Tanaman Obat Indonesia. Asam Jawa (Tamarindus Indica, Linn) http://www.iptek.net. id/ind/cakra.obat/tanamanobat.php?id=132. on November 1, 2005

2. Syahbaniah F. 2006. Evaluasi Pemanfaatan Daging Asam Jawa Terhadap Penurunan Kalkulus. Karya Tulis Ilmiah. Semarang. Jurusan Kesehatan Gigi Politeknik Kesehatan.

3. Windiyati T. 2005. Pengaruh Pemberian Asam Jawa terhadap Penurunan Kalkulus pada Ibu Rumah Tangga Usia 21-30 tahun di Desa Kelet Kec. Keling Kab. Jepara Tahun 2005. Karya Tulis Ilmiah. Semarang. Jurusan Kesehatan Gigi Politeknik Kesehatan.
4. Hariana A. 2004. Tumbuhan Obat dan Kasiatnya. Jakarta : Penebar Swadaya: 19-20.

5. Wijayakusuma H. 2004. Ensiklopedi Milenium Tumbuhan Obat Indonesia. Jakarta. Toko Gunung Agung: 71.

6. Markam. 1999. Kamus Kedokteran. Jakarta, FKUI. $2^{\text {nd }}: 9$.

7. Tarigan R. 1995. Kesehatan Gigi dan Mulut. Jakarta, EGC: 32.

8. Itjiningsih WH. 1991. Anatomi Gigi. Jakarta, EGC: 31.

9. Steel RGD and Torrie JH. 1991. Prinsip dan Prosedur Statistika - suatu pendekatan biometrik. (Translated by B. Sumantri). Jakarta. PT Gramedia Pustaka Utama, $2^{\text {nd }}$ edition. 